\title{
Chinism and the Irreversibility of Globalization: Implications for Global Governance
}

\author{
Grzegorz W. Kołodko
}

\begin{abstract}
Global governance trends from an East European perspective are the focal point of this analysis. The study suggests that in the future, none of the world's great problems can be solved without China. Irreversible globalization requires proper reinstitutionalization of global governance, which cannot happen without China's active participation. Understanding China will be key. The author coined the term 'Chinism' to advance understanding and he defines Chinism as a syncretic economic system based on multiple forms of ownership with strong macroeconomic policies and limited government control. Under this system, deregulation is subordinated to maintaining enterprises' activities on a course that is in line with the social and political goals set by the Communist Party of China. The policy of the government and the central bank, and to a lesser extent local authorities, use classic instruments of market intervention. At the same time, Chinism has helped eliminate shortages and effectively keeps price inflation in check. This is a feat none of the former models of state socialism, including the Soviet Union and CEE economies, were able to accomplish, which was the main reason behind their economic and, consequently, political demise.
\end{abstract}

Keywords Global governance trends from an East European perspective • Irreversible globalization $\cdot$ Reinstitutionalization of global governance $\cdot$ Chinism as a syncretic economic system - Classic instruments of market intervention • Soviet Union and CEE economies

\section{Introduction}

Recently, opinions have been quite often expressed that a new era is inevitably coming in which Asia and especially China will dominate the world. This is not necessarily true as certain parts of the world, specifically the European Union and United States

\footnotetext{
G. W. Kołodko ( $ه)$

Kozminski University, Warsaw, Poland

Belt and Road School, Beijing Normal University, Beijing, People's Republic Of China
} 
will still play a significant role. However, certainly the relative importance of Chinadue to the enormity of its still burgeoning economy and population-will continue to grow. It will not only have obvious economic but also political implications. In the future, none of the world's great problems will be able to be solved without China. It is, therefore, necessary not only to compete with China but also to cooperate with her in a creative manner. The sooner a culture and practice of cooperation develops, the sooner support institutions can be developed, which will be better equipped to drive the development of the global economy. Irreversible globalization requires proper reinstitutionalization of global governance, which cannot happen without China's active participation.

In the world of the future, human capital and technology will be key to the competitiveness of knowledge-based economies. However, it may not be enough to promote sustainable development. A political and economic system that favors the formation of capital and its efficient allocation will also be indispensable. In such context, a question arises: to what extent will the evolving Chinese system be able to contribute new impetus to global governance in the twenty-first century.

\section{Population and Human Capital}

The time of quantity will never end, but now the time has come for a new generation of quality. Today, and even more so in the future, economic success will depend less and less on the possession of natural resources, tangible and financial assets, and increasingly on human capital. Since the dawn of time, the economy has relied on knowledge but never has so much depended on knowledge resources as it does now. It is knowledge and the skills in leveraging it in production and trade that will determine which economy is at the leading edge. The competitiveness of economies increasingly depends on knowledge. China is fully aware of this and has accordingly invested increasing amounts of time and money in knowledge and technology.

While education and skills are of great importance, the size of each country's population should also be taken into account. China's population will soon stop growing and begin aging (Table 1).

According to United Nations projections, China's population will start to decline after 2030. In India, this turning point will not be reached until a generation later, after 2060. It is of significance in this context that India - unlike China and other countries with a quickly aging population - can leverage its demographic dividend in the form of a relatively young population, which is a contributing factor for a dynamic economy. While the median age in India is around 28 years, China's is over 37 (the global average is 30). Hence, in this respect, China's situation is already unfavorable and will continue to deteriorate.

The state of a society and the well-being of the people, especially the financial situation of individual households and the assessment of individual economic situations are not determined by economic size or by the nation's population. Being "the largest country" or "having more people" counts for something-more in political 
Table 1 Population growth forecasts, 2020-2060 (in millions)

\begin{tabular}{l|r|r|l}
\hline \multirow{2}{*}{ Country } & \multicolumn{2}{l}{ Year } & \multicolumn{2}{l}{$\begin{array}{l}\text { \% change } \\
\end{array}$} & 2020 & 2060 & \multicolumn{1}{l}{} \\
\hline China & 1,439 & 1,333 & -7.4 \\
\hline India & 1,380 & 1,651 & 19.6 \\
\hline United States & 331 & 391 & 18.1 \\
\hline Russia & 146 & 133 & -8.9 \\
\hline Japan & 126 & 98 & -22.2 \\
\hline World & 7,795 & 10,151 & 30.2 \\
\hline
\end{tabular}

Source UN (2019)

than in psychological terms - but the welfare and the subjective sense thereof has not improved as much as in China simply due to the fact that China still has the world's largest population ${ }^{1}$ and that they produce the most (based on PPP). In China, the average lifespan is only two years shorter than in the United States (77 compared to 79) and while most people see a rapidly rising average income, it still represents only $30 \%$ of the average American income, which stood at USD 62,000 per capita in 2019. These are reasons why a broader range of information is needed, rather than simple measures of per capita income. Criteria that assess the level of human capital are highly useful from this perspective.

Another key issue is the dynamic of change and global shifts that reflect differences in the level and quality of human capital. In a period of just three decades, since 1990, the average HDI (Human Development and Inequality) for the world as a whole has risen from 0.598 to 0.731 , whereas in the United States it has risen from 0.860 to 0.920 and in China from 0.501 to 0.758 . This means that 30 years ago, China was below the global average and has since risen above it. While the quality of human capital measured this way has been rising globally by $0.72 \%$ a year, the pace of growth in the United States was three times as slow $(0.24 \%)$, while in China it was twice as fast (1.48\%). Naturally, it is much easier to work your way up the ladder when you start farther down, but this is getting increasingly difficult (Table 2).

In terms of HDI, the United States ranks 15th, between New Zealand and the United Kingdom, and Belgium and Japan, ${ }^{2}$ and China, 85th, between North Macedonia and Peru above and Ecuador and Azerbaijan below. ${ }^{3}$ Norway tops the list (HDI of 0.954) and Niger is at the bottom (HDI 0.377). Taking income distribution inequality into account, which is very high in both the United States and China, with a Gini index (a measure of income inequality) of 41.5 and 38.6, respectively, the United States goes down 13 spots to number 28, while China moves up by four to

\footnotetext{
${ }^{1}$ The UN estimates that India will become the most populous country in the beginning of the fourth decade of twenty-first century. In 2035, it will have a population of 1.504 billion, while 1.464 billion people will inhabit China (UN 2019).

${ }^{2}$ In the ranking, Belgium and Japan sandwich Lichtenstein, which I omit in those comparisons.

${ }^{3}$ The ranking includes Hong Kong, which with a HDI of 0.939 ranks fourth ex equo with Germany.
} 
Table 2 Human Development and Inequality adjusted human development indices

\begin{tabular}{l|l|l|l|l|l}
\hline Country & HDI ranking & HDI & IHDI & Overall loss $(\%)$ & Change in HDI ranking \\
\hline Norway & 1 & 0.954 & 0.889 & 6.8 & 0 \\
\hline United States & 15 & 0.920 & 0.797 & 13.4 & -13 \\
\hline Japan & 19 & 0.915 & 0.882 & 3.6 & 15 \\
\hline Russia & 49 & 0.824 & 0.743 & 9.9 & 1 \\
\hline China & 85 & 0.758 & 0.636 & 16.1 & 4 \\
\hline India & 129 & 0.647 & 0.477 & 26.3 & 1 \\
\hline World & - & 0.731 & 0.584 & 20.2 & - \\
\hline
\end{tabular}

Note Overall loss: percentage difference between the IHDI value and the HDI value Source UNDP (2019), pp. 308-311

81st place (UNDP 2019), which means that the distance between them is slightly smaller than if only income is considered (Table 2).

\section{Chinism}

To solve the dilemma of choosing socialism/communism (yet) or capitalism (already), often the single criterion of the ratio of state to private ownership in the economy is used. Kornai (2008) uses this principle to claim that capitalism has existed in China since the turn of the century because as of 1998 the private sector was already delivering a larger proportion of national income. Capital markets have also been gradually developing since the beginning of market reforms. Inter alia, treasury bonds were offered for the first time in 1981, in 1984 stocks and company bonds were already being been issued and circulated, and in 1990 the Shanghai and Shenzhen Stock Exchanges - now very important on the global capital market - were established.

State-owned enterprises are particularly visible among China's largest companies. These include those in which the state has full or majority ownership as well as those in which, although there is no majority participation, it has a sufficiently large block of shares to control the company. In 2018, state-owned companies owned $88.2 \%$ of assets and took in $84.2 \%$ of revenues from a group of China's 100 largest enterprises. Of the ten largest Chinese firms, four were in the oil and gas sectors, four were in construction and two were in manufacturing; nine were state-owned. To put this in perspective, this is radically different compared with other major economies, including Germany and Japan. While state-owned enterprises dominate in China, only a few appear in Germany and Japan, mainly in infrastructure (roads, railways and post office). However, it is worth noting that, while the change is small, the number of state-owned companies in China's 100 largest companies is decreasing-from 87 in 2009 to 81 in 2018. 
China differs in terms of quality and it would be too far-fetched to classify it according to routine models. This is neither a case of communism, as some would still have it, nor of capitalism, even one adorned with this adjective or another, but that of a different quality. It is a political/social/economic system in its own right, which I refer to as Chinism (Kolodko 2018, 2020a). This is not a Beijing Consensus laden with statism and centralized bureaucracy, which some attempted to hail for a time as the antithesis for the neoliberal Washington Consensus (Halper 2010). Though one can see some analogies between those concepts, there are definitely more significant differences (Lin 2013). Neither is it a simple period of transition from a centrally planned economy to a market economy, even in the form of state capitalism (Lardy 2014).

Chinism, sui generis, is a syncretic economic system based on multiple forms of ownership of the means of production, with strong macroeconomic policies and limited government control with respect to microeconomic management. Deregulation is subordinated to maintaining enterprises' activities on a course that is in line with the social and political goals set by the Communist Party. Widely used, flexible but generally far-reaching economic interventionism uses both indicative planning that addresses the business sphere and command planning with respect to some stateowned enterprises and infrastructure. The policy of the government and the central bank, and to a lesser extent local authorities, use classic instruments of market intervention. The pricing system is essentially decentralized, which, despite a lack of fully hardened budget constraints with respect to public enterprises, guarantees that a money market equilibrium is maintained.

At the same time, Chinism has helped eliminate shortages and effectively keep price inflation in check (Kolodko 2020c). This is a feat none of the former models of state socialism, including the Soviet Union and CEE economies, were able to accomplish, which was the main reason behind their economic and, consequently, political demise (Kolodko and Rutkowski 1991; Csaba 1996).

Such a hybrid economic system comes hand in hand with a state wielding centralized power that is essentially based on meritocracy, where rational people do rational things in a rational way. The policy implemented by the state is competent and responsible. At the same time, it is oriented to fulfilling long-term strategic goals, to which medium-term and immediate goals are subordinated. The authorities also use traditional and modern social impact methods. For example, they resort to enforcing social compliance through behavior based on the general direction of development set by the Party as well as legislative and executive powers.

Chinism does not represent a turning away from the path of market reforms and to the omnipotence of the state sector in the economy; this is an overly simplified image of a highly complex reality. The state plays a major role-most of all as a regulator and also as the owner of some means of production-but it does not crowd out nor replace the market but rather corrects and supports it and creates a synergy with its forces (Huang 2017). One should not overestimate isolated events nor hastily generalize individual observations. The fact that in 2008, the prestigious post of Chief Economist and Senior Vice President of Development Economics at the World Bank was assigned to the eminent Chinese economist, Justin Yifu Lin, 
is very meaningful. This was not an empty gesture directed at China in recognition of the country's achievements from those who in fact decided it - the United States in consultation with Japan, the United Kingdom, Germany and France. It was a sign, especially to economically less developed countries, that valuable conclusions can be drawn from China's experience in creating policies on development that may be worth adopting elsewhere. Lin's term of office, 2008-2012, did not revolutionize Washington's technocratic way of thinking or the World Bank's activities, but it undoubtedly contributed to the organization's further departure from neoliberal orthodoxy.

\section{Relative Attractiveness of Chinism}

Certainly, Chinism will not be adopted by countries with liberal capitalism, but, in turn, it can be-and already is - an inspiring offer, or at least an option worth contemplating, for many developing countries that are attempting to catch up with richer ones. This is not an option for countries whose leaders believe that their strong political power and a large state sector in the economy are enough to replicate China's boom. Chinism, deeply rooted in China's unique history and culture, is much more than that.

There are several indicators typical to Chinism that already exist in the economic systems of some countries. Particular attention should be paid to large proportions of state ownership, including monopolies in strategic industries (in this case, "strategic" implies much more than in Western market economies), central planning, control of the exchange rate regime and a central bank that reports to the government. There are also certain similarities with regard to economic policy methods, especially state intervention as a means for setting industrial and trade policies, protectionism of vital sectors, state subsidies for export-oriented firms, and government influence over major inbound and outbound foreign direct investments. In the case of more technologically advanced sectors, there is often protection and state financial support to increase the international competitiveness of these companies.

Countries with liberal democracies, in the face of looming crisis, must look for ways to protect themselves against a new wave of nationalism and the crisisgenerating potential of neoliberalism (Galbraith 2018), but they will surely not follow the Chinese model. This may be done, though in very different ways, by emancipating economies and societies, especially those thrown into the category of so-called emerging markets as defined by neoliberalism (Kolodko 2014b). One important thing to note here is that two significant processes overlap: the huge economic success of Chinism and the structural crisis of liberal capitalism.

Countries that look for a lighthouse in this turbulent ocean that is the global economy may find that the light coming from Beijing is brighter than that coming from Washington and can be seen more clearly from the Pearl River Delta and Guangzhou than from New York and Manhattan. This is also supported by China's strong foreign policy. Beijing has more diplomatic posts scattered around the world 
than the United States. Its political impact cannot be underestimated, but at the same time one should not expect it to eclipse the West, including Anglo-American influence when it comes to soft power. The opening of more than a hundred Confucius Institutes in various countries, which promote China and Chinese values is a good thing. This is not a threat. On the contrary, an increased number of Mandarin speakers will also contribute to expanding international exchange in areas like education, science, culture and sports. The next round in the soft power clash will be the 24th Winter Olympic Games in Beijing in 2022, especially after the postponement of the 2020 Summer Olympics in Tokyo to 2021, due to the calamity of the COVID-19 pandemic.

China's external expansion-irrespective of its strictly economic goals, which are mainly to export major surpluses in infrastructure construction, develop outlets for increasingly competitive industries and gain access to deposits of raw materials and inputs - is pursued on a spectacular scale by means of the Belt and Road Initiative (BRI), which is often referred to as the new Silk Road (Maçães 2018). The principal purpose of the BRI is not to conquer other countries by making them economically dependent - though this, too, can happen if the recipient country is reckless and relies too much on borrowed money, so caution should be exercised-but to maintain an internal economic dynamism. Despite China's considerable size, this cannot be achieved without having recourse to external factors and further tapping into globalization for quick growth in domestic production and consumption. Over the last couple of decades, nobody has leveraged globalization so well for its own growth as China has. No wonder that it wishes to continue to do so. The Chinese are better positioned to do that, because unlike Western representatives, who tell the locals how the world should be organized on their visits to China when visiting a country the Chinese look around for solutions that may prove useful to themselves as well. No doubt, China has learned more from the West over the last few decades than the West has from China, though quite a lot of things could be learned there too.

\section{The Battle for Tomorrow: The Imperative of Inclusive Globalization}

The COVID-19 pandemic_-with its psychological and political side effects, such as growing xenophobia and mutual hostility-highlights the symptoms of protectionism and naïve mercantilism that could already be felt before (Kolodko 2020b). The financial and economic crises of 2008, driven by neoliberalism, led to a wave of new nationalist sentiment. Neoliberalism intended to help a few get rich at the expense of the majority and the public enemy was the government as the regulator and income redistribution policymaker, whereas in populism and new nationalism, the role of such a foe is reserved for globalization. This clash both weakens the capacity of countries, which may already be impaired, to focus policymaking on a multinational scale and is conducive to throwing political, social and economic relations into anarchy. 
Adding to the crisis of mishandled economic liberalization-it being improperly deregulated from the point of view of social cohesion and economic equilibriumis the crisis of liberal democracy. There are those who believe that liberalism has already collapsed (Deneen 2018). This crisis is taking different, sometimes surprising forms - one in the United States following the election of President Donald Trump and another one in Poland under the Law and Justice Party. Yet another example can be seen in Australia with its nationalist government under Prime Minister Scott Morrison and a different one in Brazil with the populist right-wing President Jair Bolsonaro. In every case, these trends harm supranational social cohesion and make it difficult for globalization to maintain a reasonable course.

This course must be based on non-orthodox economic thought, with particular importance being placed on new structural economics (Lin 2012), economics for the common good (Tirole 2017) and new pragmatism-a sort of interface between descriptive and prescriptive economics indicating the ways to integrate economic, social and environmental development into an economy of moderation (Kolodko 2014a). Economists of various contemporary theoretical schools (Galbraith 2014; Phelps 2013; Rodrik 2015; Stiglitz 2019) voice the conviction that it is possible to create a good economy.

China - the greatest beneficiary of globalization - fully grasps that, which is why (though above all, because it has its own interests at heart) is its great advocate. To save globalization and make it truly irreversible, it must become inclusive. Letting it continue in its neoliberal variety preferred by special interest groups and selfish economic and political lobbies, coinciding with adverse megatrends in the form of changes in the natural environment, global warming, uncontrollable large migrations and the COVID-19 pandemic, which has led to what I call a Yet Greater Crisis, YGC (Kolodko 2011, 2021), is not an option.

This is not only just inclusive globalization and there is no form of globalization whatsoever that can be maintained without the necessary degree of harmony between the world's two largest economies - that of China and the United States (Kissinger 2011). The hope for the development of pro publico mundiale bono cooperation and friendly rivalry as part of the so-called G2 concept-or Chimerica-was replaced with Cold War 2.0. The reason why this is so dangerous is that in addition to former President Donald Trump's extreme Sinophobia, Republicans' Democratic opponents are not fully devoid of similar sentiments. Even under President Joe Biden, it will take some time before better pragmatism-driven relations will be re-established.

A harmonized global order requires a strong and united European entity, but unfortunately, this is also being weakened due to financial and migration crises and the growing wave of new nationalism and devolutionary tendencies. Brexit is further undermining the EU, reducing its economy by around $15 \%$. Unfortunately, the European Union is becoming weaker at a time when it should gain strength to co-govern globalization's reset. The EU is both China's leading partner and strategic rival, which is not a contradiction, but a sort of dialectic.

Against such a background, another complication to this already complex equation should also be recognized: the triangle formed by China, Russia and the EU, most notably Germany. The latter wants a strong, more deeply integrated European Union. 
It also wants good, pragmatic relations with both Russia and China. To both, China is a vast market outlet; to Germany, for high-tech industrial products, to Russia, for raw materials, which are scattered across its vast territory, sprawls over eleven time zones with larger underground deposits than any other country. Geopolitical games played between these three countries have had a major impact on the geoeconomic state of the world.

China, which cares about developing cooperation with other countries and regions, at the same time is engaging them further in the globalization process. While the United States has over 200 military installations in 120 countries, China has one-a small naval base in the Horn of Africa, in Djibouti-but in contrast, is the largest trade partner for 130 countries.

Since globalization can no longer be stopped, there will be an incessant debate on what is good and bad for the world. Yes, there are good and bad economies (Kolodko 2011; Sedlacek 2011), there are systems that are more and less effective in terms of meeting their objectives, there are progressive and backward ideologies and political systems that follow them. This makes it all the more important to learn as much as possible from one another and draw on the experience of others in a creative way. Anti-examples are also useful; if only to know what not to do. China has learned a lot from others while showing a unique capacity for approaching its problems from a pragmatic standpoint rather than an ideological one-the way it used to do. Nevertheless, it still needs to learn a lot. One should hope that it would be willing and able to do so.

The British historian Ian Morris suggested one of the most interesting comparative analyses of history. He developed an original Social Development Index, which takes particular account of the energy capture, a given social culture's capacity for organization, measured with the size of its largest urban areas, war-making capacity and the advancement of information technology, determined by the speed and extent of the spread of the written word and telecommunications (Morris 2010). Using those metrics, he reaches the conclusion that the West will continue to dominate the world for only a couple of generations, after which, in the first decade of the twenty-second century, the world will be dominated by the East, the most important part being, of course, the Middle Country-China. Well, only time will tell...

A long, long time ago — the Mediterranean world knew almost nothing of Chinese civilization, but even then the smoothest silk was arriving from China. It was once said that omnes viae Romam ducunt - all roads lead to Rome. Is now the time that omnes viae Pekinam ducunt? 


\section{Conclusions}

The huge leap forward made over the past four decades by the Chinese economy as a result of market reforms and openness to the world is awe-inspiring for some and creates anxiety for others. Questions arise as to whether the foundations of China's economic success are sustainable and whether economic growth will be followed by political expansion. China has made great use of globalization and is therefore interested in its continuation. At the same time, China wants to give it new features, specific Chinese characteristics. This is met with reluctance by the current global hegemon, the United States, even more so as fears arise that China may promote abroad its uniquely original political and economic system-Chinism. However, the world is still big enough to fit us all in. What we need to make this happen is a proper policy, which, in the future, must also involve better coordination of governance at a supranational level. I believe that China can and, let us hope, will contribute to this end significantly.

\section{References}

Csaba L (1996) The political economy of the reform strategy: China and Eastern Europe compared. Communist Econ Econ Transform 8(1):53-65

Deneen PJ (2018) Why liberalism failed. Yale University Press, New Haven and London

Galbraith JK (2014) The end of normal: the great crisis and the future of growth. Simon and Schuster, New York

Galbraith JK (2018) Backwater economics and new pragmatism: institutions and evolution in the search for a sustainable economics. TIGER Working Papers Series, No. 138. Kozminski University, Warsaw. http://www.tiger.edu.p1/TWP\%20No.\%20138\%20--\%20Galbraith.pdf. Accessed 12 May 2020

Halper S (2010) The Beijing consensus: how China's authoritarian model will dominate the twentyfirst century. Basic Books, New York

Huang Y (2017) Cracking the China conundrum: why conventional economic wisdom is wrong. Oxford University Press, New York

Kissinger H (2011) On China. Penguin Press, New York

Kolodko GW (2011) Truth, errors and lies: politics and economics in a volatile world. Columbia University Press, New York

Kolodko GW (2014a) Whither the world: the political economy of the future. Palgrave-Macmillan, Houndmills, Basingstoke, Hampshire

Kolodko GW (2014b) The New Pragmatism, or economics and policy for the future. Acta Oeconomica 64(2):139-160

Kolodko GW (2018) Socialism, capitalism, or Chinism? Communist Post-Communist Stud 51(4):285-298

Kolodko GW (2020a) China and the future of globalization: the political economy of China's rise. Bloomsbury I.B. Tauris, London, New York

Kolodko GW (2020b) After the calamity: economics and politics of the post-pandemic world. Polish Sociol Rev 2(210):137-155

Kolodko GW (2020c) The Great Chinese transformation: from the third to the first world. Acta Oeconomica 70(Spec Iss)71-83 
Kolodko GW (2021) The quest for development success: bridging theoretical reasoning with economic practice. Rowman \& Littlefield, Lanham, Maryland

Kolodko GW, Rutkowski M (1991) The problem of transition from a socialist to a free market economy: the case of Poland. J Soc Polit Econ Stud 16(2):159-179

Kornai J (2008) From socialism to capitalism. Central European University Press, Budapest

Lardy NR (2014) Markets over Mao: the rise of private business in China. Peterson Institute of International Economies, Washington, DC

Lin JY (2012) New structural economics: a framework for rethinking development and policy. The World Bank, Washington DC

Lin YJ (2013) Against the consensus. Reflections on the great recession. Cambridge University Press, New York

Maçães B (2018) Belt and road: a Chinese world order. Hurts, London

Morris I (2010) Why the west rules-for now: the patterns of history and what they reveal about the future. Profile Books, London

Phelps ES (2013) Mass flourishing: how grassroots innovation created jobs, challenge, and change. Princeton University Press, New York

Rodrik D (2015) Economics rules: why economics works, when it fails, and how to tell the difference. Oxford University Press, Oxford

Sedlacek T (2011) Economics of good and evil: the quest for economic meaning from Gilgamesh to Wall Street. Oxford University Press, Oxford, New York

Stiglitz JE (2019) People, power, and profits: progressive capitalism for an age of discontent W.W. Norton, New York, London

Tirole J (2017) Economics of the common good. Princeton University Press, Princeton, New Jersey UN (2019) World population prospects 2019. United Nations, Department of Economic and Social Affairs, Populations Dynamic, New York. (https://population.un.org/wpp/Download/Probabili stic/Population/. Accessed 08 May 2020

UNDP (2019) Human development report: beyond income, beyond averages, beyond today: inequalities in human development in the 21st century. United Nations Development Programme, New York. http://www.hdr.undp.org/sites/default/files/hdr2019.pdf. Accessed 09 May 2020

Grzegorz W. Kołodko is a professor of economics, public intellectual and politician and a key architect of Polish economic reforms. He served as Deputy Prime Minister and Minister of Finance, 1994-97 and 2002-03. He is a member of the European Academy of Arts, Sciences and Humanities as well as a Honorary Doctor and Professor of dozen foreign universities. He is Founder and Director of Transformation, Integration and Globalization Economic Research, TIGER at Kozminski University in Warsaw as well as Distinguished Professor at the Belt and Road School, Beijing Normal University. He is also the author of research papers and books published in 26 languages and the world's most quoted Polish economist. He is also a marathon runner and globetrotter who has explored 170 countries and Antarctica. 
Open Access This chapter is licensed under the terms of the Creative Commons AttributionNonCommercial-NoDerivatives 4.0 International License (http://creativecommons.org/licenses/bync-nd/4.0/), which permits any noncommercial use, sharing, distribution and reproduction in any medium or format, as long as you give appropriate credit to the original author(s) and the source, provide a link to the Creative Commons license and indicate if you modified the licensed material. You do not have permission under this license to share adapted material derived from this chapter or parts of it.

The images or other third party material in this chapter are included in the chapter's Creative Commons license, unless indicated otherwise in a credit line to the material. If material is not included in the chapter's Creative Commons license and your intended use is not permitted by statutory regulation or exceeds the permitted use, you will need to obtain permission directly from the copyright holder.

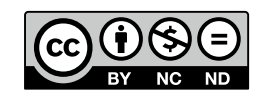

